\title{
Sugarcane Mosaic Distribution, Incidence, Increase, and Spatial Pattern in Louisiana
}

\author{
J. L. Rice, ${ }^{1}$ J. W. Hoy, ${ }^{1, \dagger}$ and M. P. Grisham ${ }^{2}$ \\ ${ }^{1}$ Department of Plant Pathology and Crop Physiology, Louisiana State University Agricultural Center, Baton Rouge, LA 70803 \\ ${ }^{2}$ Sugarcane Research Unit, U.S. Department of Agriculture - Agricultural Research Service, Houma, LA 70362
}

\begin{abstract}
Sugarcane mosaic is a historically important disease in Louisiana currently caused by sorghum mosaic virus (SrMV). Successful breeding for resistance reduced the disease to low incidence in commercial cultivars. However, mosaic was detected in experimental clone evaluations at multiple locations, leading to uncertainty concerning the current distribution and incidence in the state. Field surveys were conducted from 2016 to 2018 in breeding program yield trials and experimental clone seed cane increase fields. Mosaic symptomatic plants were observed in a newly released cultivar, HoCP 09-804, in three of five production areas, with incidences ranging from 0 to $10 \%$. Mosaic also was observed in nine

confirming that it continues to be the causal species. Runs analysis detected aggregation of infected plants within at least $70 \%$ of rows in $94 \%$ of surveyed fields. The spatial pattern and geographical distribution of disease incidence suggested that infected seed cane was the source of the disease. Surveys conducted in the same fields of HoCP 09-804 through two subsequent crops detected disease incidence increases in some fields and decreases in the others in first ratoon, but observed incidence was lower compared with plant cane in all fields in second ratoon. The results indicated that disease increase owing to aphid transmission did not occur under the prevailing conditions.
\end{abstract} additional experimental clones. Single leaf samples were tested for SrMV using reverse transcription PCR. All symptomatic samples and a low percentage $(0.3 \%)$ of asymptomatic samples tested positive for SrMV,

Keywords: disease development and spread, epidemiology, field crops, viruses and viroids

Mosaic is a viral disease of sugarcane (interspecific hybrids of the genus Saccharum) with worldwide distribution (Grisham 2000). The disease is caused by strains of sugarcane mosaic virus (SCMV) and sorghum mosaic virus (SrMV), both members of the Potyviridae (Grisham 1994; Grisham and Pan 2007). Originally, multiple virus strains were characterized and described as strains of SCMV, but taxonomic analyses of serological and chemical properties reassigned strains H, I, and M to SrMV (McKern et al. 1991; Shukla et al. 1989).

Mosaic has a long history in Louisiana and is known for nearly bankrupting the state's sugar industry in the 1920s (Koike and Gillaspie 1989). Since then, there has been an active effort to manage mosaic through breeding and selection for host plant resistance. The introduction of interspecific hybrids to replace the original Saccharum officinarum cultivars resuscitated the industry. However, periodic outbreaks of mosaic have occurred owing to virus strain changes associated with the cultivars being grown (Koike and Gillaspie 1989). Virus-tolerant cultivars were grown with high incidence of mosaic from the 1950s to the mid-1990s. Annual surveys for virus strains associated with mosaic were discontinued after it was determined that SrMV strain $\mathrm{H}$ had been the predominant strain from 1985 to 1995 until susceptibility was detected for clones in the later stages of the Louisiana sugarcane breeding program in the early 2000s (Grisham and Pan 2007). Surveys conducted from 2001 to 2003 concluded that another strain shift had occurred and that SrMV strain I had become the predominant strain (Grisham and Pan 2007).

Currently grown commercial cultivars are rated as resistant to mosaic. However, in 2016, symptoms of mosaic were observed in an advanced experimental clone, cultivar HoCP 09-804, that was being considered for commercial release and other advanced experimental clones in later stages of the sugarcane breeding program. Because sugarcane is clonally propagated, it is necessary to vegetatively

${ }^{\dagger}$ Corresponding author: J. W. Hoy; jhoy@agcenter.lsu.edu

The author(s) declare no conflict of interest.

Accepted for publication 19 March 2019.

(C) 2019 The American Phytopathological Society increase experimental clones before release of a new cultivar to farmers. In this process in Louisiana, seed cane increase fields are planted initially at three primary increase stations and then 42 secondary increase stations on cooperating commercial farms. Experimental clones also are evaluated by the breeding program in multiple-year yield trials at 12 commercial farms in different regions of the industry. The widespread presence of mosaic in experimental clone evaluation and seed cane increase plots could pose a threat for spread of the virus into commercial plantings and the reestablishment of the disease in the industry. The detection of mosaic symptomatic plants suggested a need to evaluate the current incidence and distribution of mosaic in Louisiana to assess the threat to the sugarcane industry and determine an appropriate management strategy.

Field surveys of mosaic incidence in HoCP 09-804 and other experimental clones were needed to determine the incidence and distribution of the disease, and then, potential rates of increase could be determined in subsequent ratoon crops. Mosaic incidence is determined by visual observation of characteristic symptoms consisting of patterns of contrasting shades of green in young leaves (Grisham 2000). The reliability of symptom expression as an indication of virus infection is thought to be high, but the degree of correlation between symptom expression and virus infection is uncertain. A reverse transcription PCR (RT-PCR) method capable of differentially detecting the two viruses associated with mosaic symptoms in sugarcane (Yang and Mirkov 1997) could be used to determine the virus species causing the current outbreak and the degree of reliability of survey results.

The viruses causing mosaic are transmitted in a nonpersistent manner by aphids and also spread from field to field through the planting of infected seed cane (Grisham 2000). Determining whether the source of mosaic was owing to aphid transmission or from planting virus-infected seed cane could be pertinent for developing an effective management response to the current outbreak. Sugarcane is planted as whole stalks in Louisiana, and therefore, planting of infected seed cane would result in aggregation of virus-infected plants that are produced from the same stalk. Therefore, an evaluation of the degree of within-row aggregation in fields at multiple locations could provide information concerning the relative importance of infection owing to virus-infected seed cane or aphid transmission. Ordinary runs analysis (Madden et al. 1982) would be appropriate to determine 
the randomness or aggregation of infected plants within sugarcane rows in a field and evaluate the potential role of seed cane in disease spread.

The objectives of the study were to determine the current distribution and incidence of mosaic in Louisiana sugarcane by field surveys, determine changes in incidence and rates of increase in the same fields over two subsequent seasons in ratoon crops, determine the causal virus species and reliability of visual symptoms as an indicator of virus infection using RT-PCR, and evaluate the degree of withinrow aggregation of infected plants.

\section{Materials and Methods}

In 2016, fields of experimental clones in plant cane (first-year crop) and first ratoon located at three primary and 34 secondary stations managed by the American Sugar Cane League Variety Release Program and nine outfield yield trials of the Louisiana Cooperative Sugarcane Breeding Program located on commercial farms were surveyed for incidence of mosaic. Geographic distribution was evaluated by monitoring mosaic incidence in five production areas: Bayou Teche (western), North, Upper Mississippi River (east), Lower Mississippi (east), and Bayou Lafourche (central) (Fig. 1). HoCP 09-804 was the only clone located and surveyed at the secondary stations, whereas 35 experimental clones located only at each primary station were surveyed. Twenty-two experimental clones were surveyed at each outfield trial. All fields were planted with whole stalks with a two-running stalk planting rate.

Surveys were based on the visual observation of characteristic mosaic symptoms in the young leaves of plants before stalk elongation during May. Consistency in the ability to detect symptomatic plants by survey personnel was provided by assessing a common row at locations before conducting field surveys. The number of symptomatic plants was recorded for different arbitrarily selected rows across the field at each location in "runs" (single plants and aggregations of more than one symptomatic plant). Total area surveyed was determined, and the overall percentage of infection was calculated for each location by dividing the total number of symptomatic plants recorded by the plant population in fields using an estimate of 6.6 plants per meter of row.

Symptomatic plant runs within rows were evaluated for aggregation using ordinary runs analysis (Madden et al. 1982). Z aggregation statistic values were calculated for each row at a location. Significant aggregation was considered at $Z$ aggregation values $<-1.64(P=$ $0.05)$. The percentage of rows exhibiting aggregation was then calculated for each location, and the frequency of runs for categories of

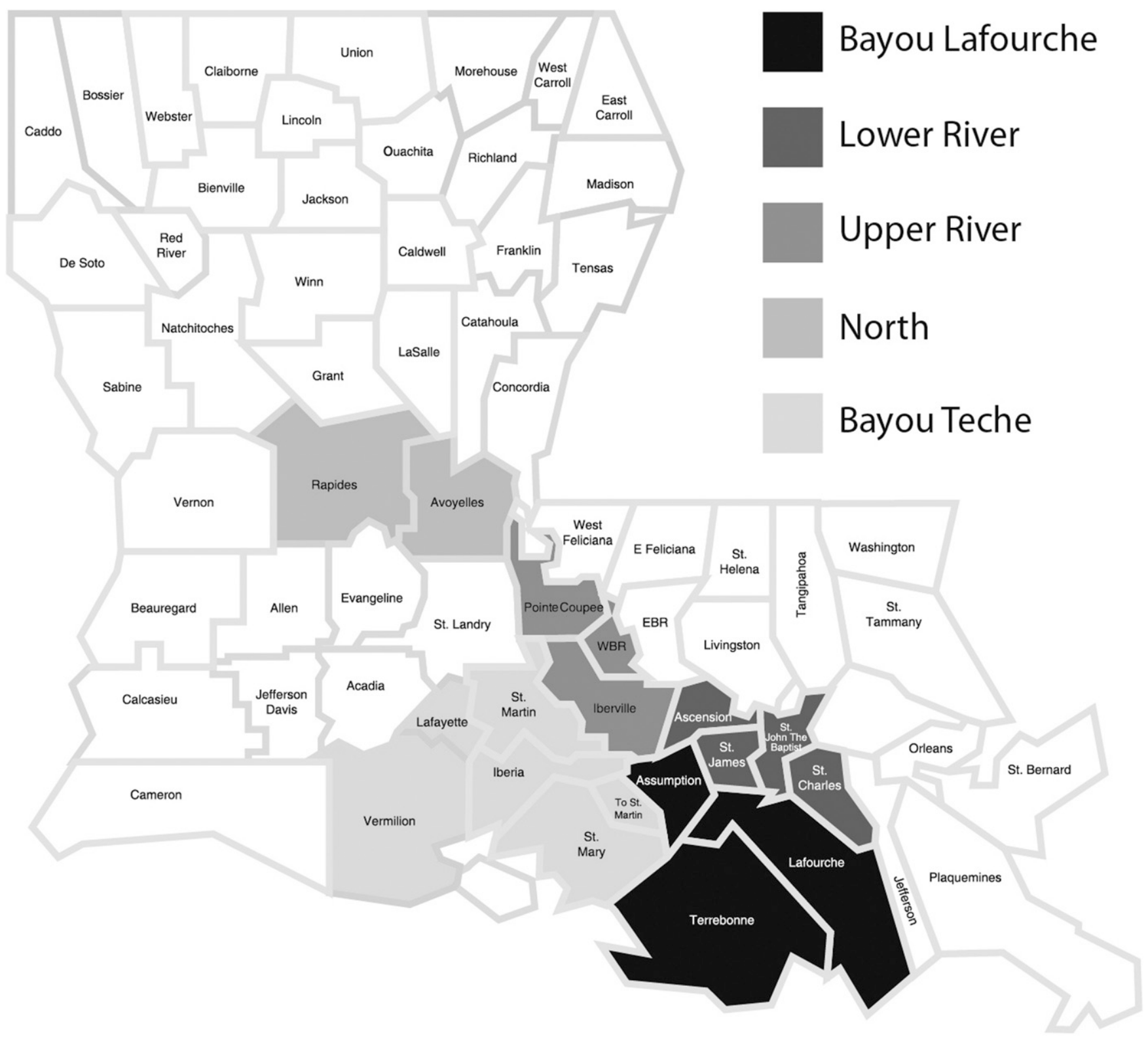

Fig. 1. Sugarcane production areas in Louisiana. 
increasing numbers of symptomatic plants per run was compared (Campbell and Madden 1990).

HoCP 09-804 fields at seven secondary stations (Raceland, Cedar Grove, Alma, Glendale, Glenwood, Little Texas, and Blackberry) where mosaic was detected were resurveyed in 2017 in first ratoon and 2018 in second ratoon by repeating the survey in the same rows as the first year. Disease rates of increase were determined by calculating the percentage change in initial incidence from plant cane to first ratoon and from plant cane to second ratoon.

In surveyed fields, single young leaf samples were arbitrarily collected from individual mosaic symptomatic and asymptomatic plants for SrMV and SCMV detection by RT-PCR (Yang and Mirkov 1997). Samples were placed in a plastic bag on ice to return to the laboratory and stored at $-70^{\circ} \mathrm{C}$ until RNA extraction was performed. Total RNA was extracted using the Spectrum Plant Total RNA Kit (Sigma Aldrich) with modifications to the tissue homogenization steps. Approximately $300 \mathrm{mg}$ of tissue was homogenized in a BIOREBA extraction bag (BIOREBA AG) with $2 \mathrm{ml}$ prepared lysis buffer from the Spectrum Plant Total RNA Kit using a BIOREBA standard rack tissue homogenizer. RT-PCR was carried out in two steps using modifications of the RT-PCR method described by Yang and Mirkov (1997). Complementary DNA synthesis was performed using the Invitrogen SuperScript First-Strand Synthesis System (Thermo Fisher Scientific), and RNA was primed with $1 \mu \mathrm{l}(2 \mu \mathrm{M}$ stock) of SrMV-R3 or SCMV-R3 (Yang and Mirkov 1997). Then, $2 \mu \mathrm{l}$ of diluted complementary DNA product in nuclease free water (1:50) was added to a $25-\mu$ l PCR solution. The PCR solution consisted of $12.5 \mu \mathrm{l}$ of GoTaq Green Master Mix, 2× (Promega), $11.86 \mu \mathrm{l}$ of nuclease free water, $0.25 \mu \mathrm{l}(10 \mu \mathrm{M}$ stock) of primers SrMV-F3 and SrMV-R3 (capable of amplifying recognized SrMV strains H, I, and M) or SCMV-F3 and SCMV-R3 (capable of amplifying recognized SCMV strains $\mathrm{A}, \mathrm{B}$, and $\mathrm{D}$ ), and $0.14 \mu \mathrm{l}$ of bovine serum albumin $\mathrm{V}(100 \mu \mathrm{g} / \mu \mathrm{l})$. The PCR program used for SrMV was $95^{\circ} \mathrm{C}$ for $2 \mathrm{~min} ; 35$ cycles of $95^{\circ} \mathrm{C}$ for $30 \mathrm{~s}, 55^{\circ} \mathrm{C}$ for $30 \mathrm{~s}$, and $72^{\circ} \mathrm{C}$ for $1 \mathrm{~min}$; and final extension at $72^{\circ} \mathrm{C}$ for $5 \mathrm{~min}$. The PCR program used for SCMV was $95^{\circ} \mathrm{C}$ for $2 \mathrm{~min} ; 35$ cycles of $95^{\circ} \mathrm{C}$ for $30 \mathrm{~s}, 51^{\circ} \mathrm{C}$ for $30 \mathrm{~s}$, and $72^{\circ} \mathrm{C}$ for $1 \mathrm{~min}$; and final extension at $72^{\circ} \mathrm{C}$ for $5 \mathrm{~min}$. RT-PCR products were electrophoresed in $2.0 \%$ agarose gel containing ethidium bromide (final concentration of $0.35 \mu \mathrm{g} / \mathrm{ml}$ ) for $1 \mathrm{~h}$, and bands were visualized using an ultraviolet transilluminator. Presence of a visible band in an electrophoresis gel at $871 \mathrm{bp}$ for SrMV and 873,885 , or 897 bp for SCMV was considered a positive test result.

Symptomatic samples were tested for SrMV from nine clones: HoCP 09-804 (193 total samples), L 10-147 (24), L 11-183 (15), Ho 11-532 (21), Ho 11-573 (1), Ho 12-626 (1), Ho 12-671 (3), L 13-242 (2), and L 13-269 (4). Asymptomatic samples were tested for SrMV from eight clones: HoCP 09-804 (250 total samples), L 10-147 (14), L 11-183 (13), Ho 11-532 (23), Ho 11-573 (1), Ho

Table 1. Mosaic incidence detected by field surveys of cultivar HoCP 09-804 in secondary station seed cane increase fields for the American Sugarcane League Variety Release Program during 2016

\begin{tabular}{|c|c|c|c|c|c|c|}
\hline Area/parish & Crop cycle year & Location & Field area (ha) & Area surveyed (\%) & $\begin{array}{l}\text { Symptomatic } \\
\text { plants }\end{array}$ & $\begin{array}{c}\text { Estimated } \\
\text { incidence }(\%)\end{array}$ \\
\hline \multicolumn{7}{|l|}{ Bayou Teche and North } \\
\hline Iberia Parish & First ratoon & Hebert & 0.1 & 100 & 0 & 0 \\
\hline Rapides Parish & Plant cane & Harper & 2.0 & 30 & 0 & 0 \\
\hline St. Martin Parish & First ratoon & Berard & 0.1 & 100 & 0 & 0 \\
\hline St. Martin Parish & First ratoon & Levert St. John & 0.2 & 100 & 0 & 0 \\
\hline St. Mary Parish & First ratoon & Adeline & 0.6 & 56 & 0 & 0 \\
\hline St. Mary Parish & First ratoon & Breaux Brothers & 0.2 & 90 & 0 & 0 \\
\hline St. Mary Parish & First ratoon & Judice & 0.1 & 100 & 0 & 0 \\
\hline St. Mary Parish & First ratoon & North Side & 0.1 & 100 & 0 & 0 \\
\hline St. Mary Parish & First ratoon & Sterling & 0.2 & 100 & 0 & 0 \\
\hline Vermilion Parish & First ratoon & Domingues & 0.2 & 67 & 0 & 0 \\
\hline Vermilion Parish & First ratoon & Duplantis & 0.2 & 100 & 0 & 0 \\
\hline \multicolumn{7}{|l|}{ Upper Mississippi River } \\
\hline Pointe Coupee Parish & Plant cane & Alma & 0.6 & 23 & 569 & 2.5 \\
\hline Pointe Coupee Parish & Plant cane & LaCour & 0.8 & 44 & 55 & 0.2 \\
\hline West Baton Rouge Parish & Plant cane & Morris & 1.0 & 50 & 74 & 0.2 \\
\hline Pointe Coupee Parish & First ratoon & Beaud & 0.3 & 100 & 15 & $<0.1$ \\
\hline Iberville Parish & First ratoon & Landry & 0.3 & 67 & 0 & 0 \\
\hline Iberville Parish & First ratoon & Pearce & 0.4 & 52 & 0 & 0 \\
\hline Iberville Parish & First ratoon & St. Louis & 0.3 & 100 & 0 & 0 \\
\hline \multicolumn{7}{|c|}{$\begin{array}{l}\text { Lower Mississippi River and Bayou } \\
\text { Lafourche }\end{array}$} \\
\hline Lafourche Parish & Plant cane & Little Texas 1 & 0.4 & 24 & 1,627 & 10.4 \\
\hline Lafourche Parish & Plant cane & Little Texas 2 & 0.4 & 100 & 1,231 & 9 \\
\hline Assumption Parish & Plant cane & Glenwood 1 & 1.6 & 100 & 411 & 1.4 \\
\hline Assumption Parish & Plant cane & Cedar Grove & 0.5 & 27 & 228 & 1.3 \\
\hline Lafourche Parish & Plant cane & Raceland & 0.6 & 44 & 264 & 1.2 \\
\hline Assumption Parish & Plant cane & $\begin{array}{l}\text { Thibodaux Brothers } \\
\text { Goldmine }\end{array}$ & 0.6 & 48 & 214 & 0.9 \\
\hline St. John Parish & Plant cane & Glendale & 0.6 & 28 & 188 & 0.9 \\
\hline Lafourche Parish & Plant cane & McCloud & 1.8 & 33 & 334 & 0.6 \\
\hline St. James Parish & Plant cane & Blackberry & 1.0 & 30 & 171 & 0.5 \\
\hline Assumption Parish & Plant cane & Glenwood 2 & 0.2 & 30 & 21 & 0.3 \\
\hline Terrebonne Parish & Plant cane & Naquin & 0.6 & 29 & 54 & 0.2 \\
\hline Ascension Parish & Plant cane & Palo Alto & 0.6 & 29 & 34 & $<0.1$ \\
\hline Lafourche Parish & Plant cane & Knight & 0.7 & 33 & 21 & $<0.1$ \\
\hline Assumption Parish & Plant cane & Belle Alliance & 1.2 & - & 12 & $<0.1$ \\
\hline St. James Parish & Plant cane & Martin and Poche & 0.6 & 25 & 8 & $<0.1$ \\
\hline Assumption Parish & Plant cane & Glenwood & 0.2 & 57 & 4 & $<0.1$ \\
\hline St. James Parish & First ratoon & Bon Secour & 0.2 & 100 & 0 & 0 \\
\hline
\end{tabular}


12-626 (1), Ho 12-671 (4), and L 13-242 (2). The assay for SCMV was performed for a subsample of symptomatic HoCP 09-804 (84), L 10-147 (24), L 11-183 (15), Ho 11-532 (21), Ho 11-573 (1), Ho 12-626 (1), Ho 12-671 (3), L 13-242 (2), L 13-269 (4), and asymptomatic samples from all clones (306; two asymptomatic samples from 2018 were not tested for SCMV).

\section{Results}

Incidence of mosaic for the 2016 survey of HoCP 09-804 in secondary station increase fields at different locations ranged from 0 to $3.5 \%$, except for in two fields at Little Texas that had incidences of 9.0 and $10.4 \%$ (Table 1). In the Bayou Teche and North areas, no mosaic was detected, whereas the Upper and Lower Mississippi River and Bayou Lafourche areas had locations with and without mosaic incidence (Table 1). In fields at the three primary stations, mosaic was detected in a total of 6 of 35 (17.1\%) experimental clones. Percentage of symptomatic plants was calculated for each clone when mosaic was detected: L $10-147(10.1 \%$ at one of three locations), L 11-183 (0.4\% at one location), Ho 11-512 (0.5\% at one location), Ho $11-532$ (1.4\% at one location and $0.6 \%$ at a second location), Ho 12-626 (0.1\% at two locations), and HoCP 12-671 ( $0.2 \%$ at one location). In the breeding program outfield yield trials,

Table 2. Reverse transcription PCR assay results for sorghum mosaic virus (SrMV) detection in mosaic symptomatic and asymptomatic leaves collected from advanced experimental sugarcane clones during field surveys conducted from 2016 to 2018

\begin{tabular}{llcccrrr}
\hline & & \multicolumn{2}{c}{ Asymptomatic } & & \multicolumn{2}{c}{ Symptomatic } \\
\cline { 3 - 4 } \cline { 6 - 7 } Year & \multicolumn{1}{c}{ Clone } & $\begin{array}{c}\text { Number of } \\
\text { samples }\end{array}$ & $\begin{array}{c}\text { Number } \\
\text { of SrMV } \\
\text { positive (\%) }\end{array}$ & & $\begin{array}{c}\text { Number } \\
\text { of samples }\end{array}$ & $\begin{array}{r}\text { Number } \\
\text { of SrMV } \\
\text { positive (\%) }\end{array}$ \\
\hline 2016 & HoCP 09-804 & 168 & $0(0)$ & & 115 & $115(100)$ \\
2016 & L 10-147 & 14 & $0(0)$ & & 24 & $24(100)$ \\
2016 & L 11-183 & 5 & $0(0)$ & & 5 & $5(100)$ \\
2016 & Ho 11-532 & 12 & $0(0)$ & & 11 & $11(100)$ \\
2016 & Ho 12-626 & 1 & $0(0)$ & & 1 & $1(100)$ \\
2016 & Ho 12-671 & 4 & $0(0)$ & & 3 & $3(100)$ \\
2016 & L 13-242 & 2 & $0(0)$ & & 2 & $2(100)$ \\
2016 & L 13-269 & - & - & & 4 & $4(100)$ \\
2017 & HoCP 09-804 & 82 & $1(1.2)$ & & 78 & $78(100)$ \\
2017 & L 11-183 & 6 & $0(0)$ & & 6 & $6(100)$ \\
2017 & Ho 11-532 & 11 & $0(0)$ & & 10 & $10(100)$ \\
2017 & Ho 11-573 & 1 & $0(0)$ & & 1 & $1(100)$ \\
2018 & L 11-183 & 2 & $0(0)$ & & 4 & $4(100)$ \\
Total & HoCP 09-804 & 250 & $1(0.4)$ & 193 & $193(100)$ \\
Total & All clones & 308 & $1(0.3)$ & 264 & $264(100)$ \\
\hline
\end{tabular}

mosaic was detected in 4 of $22(18.2 \%)$ experimental clones across nine locations, and the percentage of infected plants was calculated in each case: $\mathrm{L} 10-147(2.2,11.6,11.6,23.9,27.2,28.2$, and $31.9 \%)$, L 13-263 (3.6\%), L 13-242 (1.4\%), and Ho 13-769 (4.3\%).

Leaf samples from HoCP 09-804, L 10-147, L 11-183, Ho 11-532, Ho 11-573, Ho 12-626, Ho 12-671, L 13-242, and L 13-269 were tested for SrMV by RT-PCR. All 264 symptomatic leaf samples from all experimental clones tested across three seasons were positive for SrMV. Only 1 of $250(0.4 \%)$ asymptomatic samples from HoCP 09804 tested positive; all other asymptomatic samples were negative for SrMV (Table 2). A total of 306 asymptomatic samples from multiple experimental clones, 84 symptomatic samples from HoCP 09-804, and 71 symptomatic samples from other experimental clones tested negative for SCMV by RT-PCR.

The runs analysis of 17 plant cane fields of HoCP 09-804 detected aggregation of symptomatic plants within $\geq 70 \%$ of the rows for 16 of $17(94.1 \%)$ locations, and the mean number of plants in a run ranged from 1.2 to 4.7 (Table 3 ). Six categories of numbers of plants per run $(1,2,3$ to 6,7 to 12,13 to 24 , and $>24$ symptomatic plants per run) were used to evaluate the occurrence of runs with increasing numbers of plants (Table 3 ). The percentages for single plants ranged from 11 to $79 \%$ across fields, two plants per run ranged from 16 to $40 \%$, three to six plants per run ranged from 5 to $68 \%$, seven to 12 plants per run ranged from 0 to $23 \%, 13$ to 24 plants per run ranged from 0 to $10 \%$, and $>24$ plants ranged from 0 to $2 \%$ (Table 4). Overall, symptomatic plants occurred in runs of $>1$ plant $64 \%$ of the time, but only $12 \%$ of runs consisted of $>6$ plants and $4 \%$ consisted of $>12$ plants (Table 4).

In first ratoon during 2017, disease incidence in different fields both increased and decreased, but in second ratoon during 2018, all locations experienced a decrease in disease levels from the 2016 initial infection incidence (Fig. 1). Changes in mosaic incidence from plant cane to first ratoon for the seven locations ranged from -8.8 to $+98 \%$, and they ranged from -44 to $-100 \%$ in second ratoon (Table 5). The greatest increase of disease was observed in 2017 at Raceland, where the initial incidence increased from 4.0 to $7.9 \%$.

\section{Discussion}

Field observations of mosaic symptomatic plants in advanced experimental clones in the sugarcane breeding program during 2016 prompted concern about a possible reemergence of the historically important disease in Louisiana. Field surveys successfully determined the current distribution and incidence of mosaic in different areas of the industry. HoCP 09-804 had been vegetatively increased throughout the industry to facilitate distribution on commercial release. Mosaic incidence was either low or absent in fields of HoCP 09-804 that were surveyed during 2016, except for in two fields at

Table 3. Results of runs analysis to evaluate aggregation of mosaic symptomatic plants within rows of cultivar HoCP $09-804$ in fields surveyed during 2016

\begin{tabular}{|c|c|c|c|c|c|}
\hline Parish & Location & Cultivar & Mean plants per run & Rows with aggregation (\%) & $Z^{\mathrm{a}}$ range \\
\hline Assumption & Little Texas & L $11-532$ & 4.7 & $6 / 7(86)$ & -38.4 to 1.5 \\
\hline Pointe Coupee & Alma 1 & НоСР 09-804 & 4 & $5 / 5(100)$ & -29.4 to -10.2 \\
\hline Pointe Coupee & LaCour & НоСР 09-804 & 4 & $7 / 7(100)$ & -35.4 to -14.2 \\
\hline Assumption & Thibodaux Brothers French & НоСР 09-804 & 3.9 & $8 / 8(100)$ & -37.5 to -11.8 \\
\hline St. John & Glendale & НоСР 09-804 & 3.3 & $8 / 8(100)$ & -34.8 to -14.9 \\
\hline Assumption & Little Texas 1 & НоСР 09-804 & 3.2 & $7 / 7(100)$ & -33.9 to -14.1 \\
\hline Assumption & Little Texas 2 & НоСР 09-804 & 3.1 & $8 / 8(100)$ & -33.4 to -23.0 \\
\hline Pointe Coupee & Alma 2 & НоСР 09-804 & 3 & $13 / 15(87)$ & -31.6 to 1.3 \\
\hline Terrebonne & Naquin & НоСР 09-804 & 2.8 & $8 / 8(100)$ & -32.7 to -21.9 \\
\hline Assumption & Little Texas & L $11-183$ & 2.5 & $7 / 7(100)$ & -30.1 to -15.1 \\
\hline Lafourche & McCloud & НоСР 09-804 & 2.4 & $23 / 28(82)$ & -35.6 to 1.6 \\
\hline St. James & Blackberry & НоСР 09-804 & 2.2 & $12 / 14(86)$ & -31.9 to 1.6 \\
\hline West Baton Rouge & Morris & НоСР 09-804 & 2.2 & $6 / 6(100)$ & -45.2 to -15.6 \\
\hline Lafourche & Raceland & НоСР 09-804 & 2.1 & 10/11 (91) & -24.8 to 1.2 \\
\hline Assumption & Glenwood 1 & НоСР 09-804 & 1.8 & $25 / 33(76)$ & -22.4 to 1.2 \\
\hline Assumption & Cedar Grove & НоСР 09-804 & 1.5 & $7 / 10(70)$ & -27.6 to 0.50 \\
\hline Assumption & Glenwood 2 & НоСР 09-804 & 1.2 & $3 / 9(33)$ & -14.4 to 1.1 \\
\hline
\end{tabular}

${ }^{a} Z$ aggregation statistic values were calculated for each row at a location; values $<-1.64(P=0.05)$ were considered to exhibit significant aggregation. 
the Little Texas Primary Station with incidences of 9.0 and $10.4 \%$. The distribution of mosaic incidence was variable across the geographic areas of the industry. Mosaic symptomatic plants of HoCP 09-804 were not detected in the Bayou Teche and North areas, whereas mosaic was detected in some locations but not others in the Upper Mississippi River, Lower Mississippi River, and Bayou Lafourche areas.

The Louisiana Cooperative Sugarcane Breeding Program is conducted at facilities associated with the Louisiana State University Agricultural Center and the U.S. Department of Agriculture Agricultural Research Service Sugarcane Research Unit and on cooperating commercial farms. Seed cane from experimental clones is obtained from the respective agency research farms and planted at three primary stations and 42 secondary stations of the American Sugar Cane League Variety Release Program located on commercial farms. Chance distribution of virus-free or systemically infected seed cane to these locations could be the cause of the pattern of geographic distribution and disease incidence detected in the surveys of HoCP 09-804. Mosaic was not detected at secondary stations in the Bayou Teche and North areas that were supplied with seed cane increased at the primary station in the Bayou Teche area in contrast to the detection of mosaic at the secondary stations in other areas planted with seed cane from the two primary stations in the Bayou Lafourche area, in particular the Little Texas Primary Station that had the highest disease incidence. These results support the hypothesis that infected seed cane was the origin for the new disease outbreak rather than spread by migrating aphids.

All symptomatic leaf samples tested positive for SrMV using the RT-PCR detection method developed by Yang and Mirkov (1997). These results indicate that SrMV is the virus species responsible for the current outbreak. Additional confirmation is needed to determine whether the strain occurring in infections is SrMV strain H, I, or M (Yang and Mirkov 1997). There were no samples for which the causal virus was unidentifiable using the Yang and Mirkov primers in contrast to a previous survey (Grisham and Pan 2007). In addition, there were no symptomatic samples that tested positive for SCMV, and therefore, it is unlikely that there are frequent occurrences of SrMV and SCMV coinfections. The lack of samples that tested positive for SCMV also suggests a continuance of the absence of this virus species that was indicated by the field surveys conducted by Grisham and Pan (2007). The low percentage (0.3\%) of asymptomatic samples that tested positive for SrMV suggests a rarity of asymptomatic infections and provides support for the reliability of field surveys based on observation of visual symptoms.
Runs analysis of the incidence results from surveyed fields of multiple clones in plant cane showed that most of the fields exhibited extensive aggregation of symptomatic plants within rows. The occurrence of single symptomatic plants could suggest aphid spread of mosaic into and within fields, and local aphid movement to adjacent plants could then result in runs of infected plants. The planting of whole infected stalks also would result in multiple symptomatic plants occurring together. The consistent aggregated disease spatial pattern detected within rows planted with whole stalks across locations considered along with the geographic distribution pattern detected supports the hypothesis that the initial occurrence of mosaic was because of the planting of infected seed cane. The spatial pattern of other nonpersistently transmitted virus species has differed within a crop. A spatial pattern analysis of plum pox virus strain $\mathrm{M}$ concluded that a range from no aggregation to high levels of aggregation could be observed in symptomatic peach (Prunus persica) trees (Dallot et al. 2003). Studies in narrow-leafed lupin (Lupinus

Table 5. Change in incidence of mosaic symptomatic plants in fields of cultivar HoCP 09-804 from plant cane to first and second ratoon

\begin{tabular}{lccc}
\hline & $\begin{array}{c}\text { 2016 Initial } \\
\text { infection } \\
\text { incidence in } \\
\text { plant cane, \% }\end{array}$ & $\begin{array}{c}\text { 2017 Infection } \\
\text { incidence and } \\
\text { percentage } \\
\text { change in first } \\
\text { ratoon, \% }\end{array}$ & $\begin{array}{c}\text { 2018 Infection } \\
\text { incidence and } \\
\text { percentage } \\
\text { change in second } \\
\text { ratoon, \% }\end{array}$ \\
$\begin{array}{l}\text { Parish } \\
\text { (location) }\end{array}$ & 1.0 & $1.6(+60)$ & $0.3(-70)$ \\
\hline $\begin{array}{c}\text { Assumption } \\
\text { (Cedar Grove) }\end{array}$ & 1.0 & $0.7(-30)$ & $0.0(-100)$ \\
$\begin{array}{c}\text { Assumption } \\
\text { (Glenwood) }\end{array}$ & 6.8 & $4.1(-39)$ & $1.0(-85)$ \\
$\begin{array}{c}\text { Assumption } \\
\text { (Little Texas) }\end{array}$ & 4.0 & $7.9(+98)$ & $2.0(-50)$ \\
$\begin{array}{c}\text { Lafourche } \\
\text { (Raceland) }\end{array}$ & 6.8 & $6.2(-9)$ & $2.6(-62)$ \\
$\begin{array}{c}\text { Pointe Coupee } \\
\text { (Alma) }\end{array}$ & 0.9 & $0.4(-56)$ & $0.5(-44)$ \\
$\begin{array}{c}\text { St. James } \\
\text { (Blackberry) }\end{array}$ & 1.6 & $1.2(-25)$ & $0.2(-88)$ \\
$\begin{array}{c}\text { St. John } \\
\text { (Glendale) }\end{array}$ & & & \\
\hline
\end{tabular}

${ }^{a}$ Initial infection percentages were calculated only from rows that were resurveyed.

${ }^{b}$ Percentage change is calculated from the change in incidence from plant cane to second ratoon.

Table 4. Runs of mosaic symptomatic plants recorded by categories with increasing numbers of plants per run in cultivar HoCP 09-804 field surveys conducted during 2016

\begin{tabular}{|c|c|c|c|c|c|c|c|c|}
\hline \multirow[b]{2}{*}{ Parish } & \multirow[b]{2}{*}{ Location } & \multirow[b]{2}{*}{ Clone } & \multicolumn{6}{|c|}{$\begin{array}{l}\text { Runs grouped by categories for number of } \\
\text { symptomatic plants per run }(\%)\end{array}$} \\
\hline & & & 1 & 2 & $3-6$ & $7-12$ & $13-24$ & $>24$ \\
\hline Assumption & Cedar Grove & НоСР 09-804 & $43(64)$ & $14(21)$ & $9(13)$ & $1(2)$ & $0(0)$ & $0(0)$ \\
\hline Assumption & Glenwood 1 & НоСР 09-804 & $74(58)$ & $25(20)$ & $27(21)$ & $1(1)$ & $0(0)$ & $0(0)$ \\
\hline Assumption & Glenwood 2 & НоСР 09-804 & $15(79)$ & $3(16)$ & $1(5)$ & $0(0)$ & $0(0)$ & $0(0)$ \\
\hline Assumption & Little Texas & НоСР 09-804 & $157(34)$ & $104(23)$ & $140(30)$ & $46(10)$ & $16(4)$ & $0(0)$ \\
\hline Assumption & Little Texas & НоСР 09-804 & $99(35)$ & $58(20)$ & $73(25)$ & $34(12)$ & $19(7)$ & $4(1)$ \\
\hline Assumption & Thibodaux Brothers French & НоСР 09-804 & $42(27)$ & $31(20)$ & $58(37)$ & $19(12)$ & $5(3)$ & $0(0)$ \\
\hline Lafourche & McCloud & НоСР 09-804 & $48(36)$ & $33(25)$ & $45(34)$ & $7(5)$ & $0(0)$ & $1(1)$ \\
\hline Lafourche & Raceland & НоСР 09-804 & $63(54)$ & $31(27)$ & $16(14)$ & $5(4)$ & $1(1)$ & $0(0)$ \\
\hline Pointe Coupee & Alma 1 & НоСР 09-804 & $15(16)$ & $23(25)$ & $39(42)$ & $11(12)$ & $4(4)$ & $2(2)$ \\
\hline Pointe Coupee & Alma 2 & НоСР 09-804 & $31(26)$ & $26(22)$ & $39(33)$ & $16(13)$ & $6(5)$ & $2(2)$ \\
\hline Pointe Coupee & LaCour & НоСР 09-804 & $3(23)$ & $3(23)$ & $4(31)$ & $3(23)$ & $0(0)$ & $0(0)$ \\
\hline St. James & Blackberry & НоСР 09-804 & $33(41)$ & $23(28)$ & $23(28)$ & $2(3)$ & $0(0)$ & $0(0)$ \\
\hline St. John & Glendale & НоСР 09-804 & $21(38)$ & $14(26)$ & $16(29)$ & $3(6)$ & $1(2)$ & $0(0)$ \\
\hline Terrebonne & Naquin & НоСР 09-804 & $2(11)$ & $4(21)$ & $13(68)$ & $0(0)$ & $0(0)$ & $0(0)$ \\
\hline West Baton Rouge & Morris & НоСР 09-804 & $7(25)$ & $11(40)$ & $9(32)$ & $0(0)$ & $1(4)$ & $0(0)$ \\
\hline Assumption & Little Texas & L 11-183 & $7(26)$ & $8(30)$ & $12(44)$ & $0(0)$ & $0(0)$ & $0(0)$ \\
\hline Assumption & Little Texas & L 11-532 & $10(20)$ & $5(10)$ & $20(41)$ & $9(18)$ & $5(10)$ & $0(0)$ \\
\hline Total & & & $669(36)$ & $416(23)$ & $544(29)$ & $157(8)$ & $58(3)$ & $9(1)$ \\
\hline
\end{tabular}


angustifolius) observed different types of spatial patterns owing to aphid transmission for cucumber mosaic virus (CMV) and bean yellow mosaic virus (BYMV) from primary inoculum sources in which CMV spread occurred in large aggregations, whereas BYMV spread exhibited diffuse patterns (Jones 2005).

Repeat surveys of multiple locations in first and second ratoon provided information on potential rates of disease increase owing to aphid transmission. Mosaic incidence increased at some locations and decreased at others in first ratoon; then, incidence decreased at all locations in second ratoon. The greatest increase in incidence occurred in first ratoon at Raceland, where the number of infected plants increased $97 \%$, but with an initial incidence of $4 \%$, the change in infection did not result in a high level of disease. A higher rate of initial incidence, $6.8 \%$ at Little Texas, did not result in a higher rate of increase, because incidence was progressively lower at this location in two subsequent ratoon crops. The low rates of disease increase and decreases in incidence observed in the majority of cases suggest that disease spread by migrating aphids was not effective during the 2 additional survey years. However, the annual spring and fall aphid migrations were not monitored as part of the study. The low initial incidence in plant cane and lack of other inoculum sources were likely additional contributing factors. Informal surveys conducted in commercial fields surrounding the surveyed fields did not detect any mosaic symptomatic plants. The lack of disease increase at multiple locations suggested that the potential for rapid rates of mosaic increase is currently unlikely in Louisiana. However, the explanation for disease decreases from one crop year to the next is uncertain. The occurrence of recovery from mosaic has been documented in sugarcane in Louisiana (Benda 1974; Summers et al. 1948), and this may have contributed to the decreases in the number of symptomatic plants observed in ratoon crops. It also is possible that mosaicinfected plants are less able to survive winter freezes than healthy plants as has been documented for smut (Sporisorium scitamineum)-infected plants (Hoy et al. 1987).

In summary, mosaic incidence was found to be generally low or absent in the surveyed locations of the Louisiana sugarcane breeding program. RT-PCR results for field-collected leaf samples indicated that SrMV continues to be the virus species causing mosaic and confirmed the accuracy of using the visual observation of symptoms in plants for determining disease incidence. The geographic distribution, consistent aggregation, and numbers of plants in runs suggest that the source of the initial infection in the current outbreak was the planting of infected seed cane. The lack of disease increase over two seasons and the continued failure to detect mosaic in fields of current commercial cultivars indicated that, under the current conditions, mosaic is not rapidly reemerging as a problem disease. However, the past history of the disease in Louisiana, the existing known genetic variation in SCMV (Wu et al. 2012), the detection of virus isolates not matching known strains in Louisiana (Grisham and Pan 2007), the seasonal variation in aphid species and abundance, and variable susceptibility levels in different host genotypes are all reasons for continued careful disease monitoring and ongoing breeding for host plant resistance.

\section{Acknowledgments}

The authors acknowledge Carolyn Savario for her technical assistance; Kathryn Warnke for advice related to reverse transcription PCR; and Atticus Finger and Herman Waguespack from the American Sugar Cane League and Edwis Dufrene, Lawrence Lovell, Jeri Maggio, and Kathryn Warnke from the U.S. Department of Agriculture Sugar Research Unit for their assistance in the field surveys.

\section{Literature Cited}

Benda, G. T. A. 1974. The recovery of sugarcane from infection with sugarcane mosaic virus: Variety Co. 285 and strain D. Proc. Amer. Soc. Sugar Cane Technol. 3:65-73

Campbell, C. L., and Madden, L. V. 1990. Spatial aspects of plant disease epidemics II: Analysis of spatial pattern. Pages 295-299 in: Introduction to Plant Disease Epidemiology. John Wiley \& Sons Inc., New York, NY.

Dallot, S., Gottwald, T., Labonne, G., and Quiot, J.-B. 2003. Spatial pattern analysis of sharka disease (plum pox virus strain $\mathrm{m}$ ) in peach orchards of southern France. Phytopathology 93:1543-1552.

Grisham, M. P. 1994. Strains of sorghum mosaic virus causing sugarcane mosaic in Louisiana. Plant Dis. 78:729-732.

Grisham, M. P. 2000. Mosaic. Pages 249-254 in: A Guide to Sugarcane Diseases. P. Rott, R. A. Bailey, J. C. Comstock, B. J. Croft, and A. S. Saumtally, eds. CIRAD/ISSCT, La Librairie du Cirad, Montpellier, France.

Grisham, M. P., and Pan, Y. B. 2007. A genetic shift in the virus strains that cause mosaic in Louisiana sugarcane. Plant Dis. 91:453-458.

Hoy, J. W., Grisham, M. P., and Benda, G. T. A. 1987. Effect of Louisiana growing conditions on the overwintering of smut-infected plants. Sugar Cane 3:11-15.

Jones, R. 2005. Patterns of spread of two non-persistently aphid-borne viruses in lupin stands under four different infection scenarios. Ann. Appl. Biol. 146: 337-350.

Koike, H., and Gillaspie, A. G., Jr. 1989. Mosaic. Pages 301-322 in: Diseases of Sugarcane-Major Diseases. C. Ricaud, B. T. Egan, A. G. Gillaspie, Jr., and C. G. Hughes, eds. Elsevier Science Publishers, Amsterdam, The Netherlands.

Madden, L. V., Louie, R., Abt, J. J., and Knoke, J. K. 1982. Evaluation of tests for randomness of infected plants. Phytopathology 72:195-198.

McKern, N. M., Shukla, D. D., Toler, R. W., Jensen, S. G., Tosic, M., Ford, R. E., Leon, O., and Ward, C. W. 1991. Confirmation that the sugarcane mosaic-virus subgroup consists of four distinct potyviruses by using peptide profiles of coat proteins. Phytopathology 81:1025-1029.

Shukla, D. D., Tosic, M., Jilka, J., Ford, R. E., Toler, R. W., and Langham, M. A C. 1989. Taxonomy of potyviruses infecting maize, sorghum, and sugarcane in Australia and the United States as determined by reactivities of polyclonal antibodies directed towards virus-specific n-termini of coat proteins. Phytopathology 79:223-229.

Summers, E. M., Brandes, E., and Rands, R. 1948. Mosaic of sugarcane in the United States, with special reference to strains of the virus. U.S. Department of Agriculture Technical Bulletin 955. USDA, Washington, DC.

Wu, L., Zu, X., Wang, S., and Chen, Y. 2012. Sugarcane mosaic virus-long history but still a threat to industry. Crop Prot. 42:74-78.

Yang, Z. N., and Mirkov, T. E. 1997. Sequence and relationships of sugarcane mosaic and sorghum mosaic virus strains and development of RT-PCR-based RFLPs for strain discrimination. Phytopathology 87:932-939. 